\title{
ZHANG YIMOU - TWÓRCA NIEZALEŻNY, TWÓRCA KONIUNKTURALNY? METAMORFOZY ARTYSTY W PAŃSTWIE KOMUNISTYCZNYM
}

Chiny doby komunizmu praktycznie od początku istnienia Republiki Ludowej aż po dzień dzisiejszy znajdowały się w sytuacji ciagłego wewnętrznego konfliktu, który radykalnie wpływał na kondycję całego społeczeństwa. Pierwsze dekady komunizmu w Państwie Środka, związane nierozerwalnie z postacią Mao Zedonga, oznaczały dramatyczne w przebiegu i skutkach zderzenie tradycyjnych wartości z nowym komunistycznym ładem. Punktem kulminacyjnym owego zderzenia była rewolucja kulturalna (1966-1976), kiedy to próbowano zanegować cały dotychczasowy dorobek kulturowy Chin. Po śmierci Mao rewolucja dobiegła końca, a Państwo Środka znalazło się w kolejnym punkcie zwrotnym. Wszystkie wcześniejsze założenia polityki zarówno wewnętrznej, jak i zagranicznej okazały się chybione. Gospodarka znajdowała się w opłakanym stanie i „trudno było nie zauważyć, że kraje azjatyckie przyjmujące gospodarkę rynkową rozwijają się szybciej od ChRL"1, zwłaszcza że w gronie ,azjatyckich tygrysów” znajdowały się zamieszkane przez Chińczyków Tajwan, Hongkong i Singapur. W tej sytuacji polityka „otwartych drzwi” i wolnorynkowej transformacji, forsowana przez reformistę i technokratę Denga Xiaopinga, stanowiła jedyną sensowna drogę rozwoju. Oznaczało to kolejny gwałtowny zwrot, do którego każdy mieszkaniec Chin musiał się w jakiś sposób ustosunkować.

$\mathrm{Na}$ gruncie owych dwóch rewolucji - kulturalnej i wolnorynkowej - wyrosło nowe pokolenie kina chińskiego zwane piątą generacją. Jednym z jej czołowych przedstawicieli jest Zhang Yimou, reżyser znany na całym świecie, ceniony przez krytykę i widownię festiwalową, ale nieobcy również odbiorcy masowemu. W jego dorobku znajdują się zarówno dzieła awangardowe i kameralne, trafiające przede wszystkim w gusta koneserów kina artystycznego, jak i wysokobudżetowe spektakle historyczne, cieszące się ogromną popularnością wśród publiczności i w konsekwencji przynoszące znaczne zyski. W kontekście rozważań na temat funkcjonowania jednostki w państwie komunistycznym życie i twórczość Zhanga Yimou

1 J. Polit, Chiny, Warszawa 2004, s. 273. 
stanowią szczególnie wartościowy materiał badawczy, ponieważ w pewnym sensie odzwierciedlają drogę całego pokolenia artystów - od eksperymentów związanych z poszukiwaniem własnej tożsamości w pierwszej dekadzie po rewolucji kulturalnej, poprzez prodemokratyczny bunt na przełomie lat 80. i 90., aż do „flirtu” z władzą totalitarną i sztuką komercyjną w nowym stuleciu.

Jak zauważyła Alicja Helman w jednym ze swoich szkiców na temat Zhanga: ,,rozważane z pewnej perspektywy filmy reżysera układają się w cykle"2. W niniejszym artykule podjęto próbę wyodrębnienia takich cykli w twórczości artysty, przy czym podstawowym kryterium nie jest w naszym przypadku treść ani styl obrazów, lecz odbijająca się w nich postawa reżysera względem dynamicznie zmieniającej się rzeczywistości społeczno-politycznej w komunistycznych Chinach przełomu tysiącleci.

\section{Młodość w cieniu Mao Zedonga}

Zhang Yimou urodził się w 1951 r. w Xi'an, stolicy prowincji Shaanxi. Podobnie jak większość pozostałych przedstawicieli piątej generacji należał zatem do pokolenia „dzieci Mao”, to znaczy „urodzonych po zwycięstwie komunistów w 1949 r. i od najwcześniejszych dni wychowywanych w duchu ideologii komunistycznej"3. Jego rodzice natomiast wywodzili się z przedrewolucyjnej inteligencji - matka była lekarka, ojciec zaś oficerem armii Kuomintangu, głównego przeciwnika komunistów w ciagnacej się od lat 20. XX wieku wojnie domowej. W praktyce oznaczało to, że cała rodzina znajdowała się na celowniku nowych władz jako złożona z potencjalnych wrogów ludu. Na domiar złego wujek i starszy brat Zhanga ewakuowali się wraz z wycofującą się armią nacjonalistów na Tajwan. Konsekwencje dla młodego Zhanga Yimou miały nadejść wraz z rozpoczęciem rewolucji kulturalnej.

W 1966 r. w myśl teorii „,permanentnej rewolucji” i tezy o zaostrzającej się walce klasowej Mao Zedong uznał ówczesne kierownictwo partii za „rewizjonistów zmierzających do restauracji kapitalizmu"4, a całą przedrewolucyjną kulturę Chin za relikt przeszłości, hamujący rozwój nowego, komunistycznego społeczeństwa. Oparł się przy tym na dwóch siłach: Armii Ludowo-Wyzwoleńczej, a także - co miało mieć szczególnie szkodliwe konsekwencje „dla moralnego rozwoju całego pokolenia" ${ }^{5}$ - młodzieży chińskiej. To spośród niej rekrutowali się członkowie Czerwonej

\footnotetext{
2 A. Helman, Wiejskie kino Zhanga Yimou, „Kwartalnik Filmowy” 2005, nr 51, s. 23.

„born after the Communist victory of 1949 and carefully nurtured in Communist ideology from their first days in kindergarten", Y. Zhu, B. Robinson, The Cinematic Transition of the Fifth Generation Authers [w:] Art, politics, and commerce in Chinese cinema, eds. Y. Zhu, S. Rosen, Hong Kong 2010, s. 146.

4 W. Rodziński, Historia Chin, Wrocław 1992, s. 708.

5 Ibidem.
} 
Gwardii, znanej jako ruch hunwejbinów (od hong - czerwony, weibing-gwardzista). Idąc tropem myśli Mao, że „trzy tysiące lat historii ciąży nad nami”, młodzi rewolucjoniści przystapili do systematycznego niszczenia zabytków sztuki i architektury oraz do masowych prześladowań inteligencji.

Rodzinę Zhangów zaliczono do jednej z pięciu „czarnych kategorii”’’, którym to mianem określano klasy wrogie rewolucji. Młody Yimou został wyrzucony ze szkoły, a w 1969 r. zesłany na wieś w ramach akcji reedukacji młodzieży - najpierw przez 3 lata pracował na roli, następnie przez 7 lat w fabryce tekstyliów ${ }^{8}$. Paradoksalnie, to $\mathrm{w}$ tych trudnych warunkach poczynił pierwsze kroki, by zostać filmowcem - zaczął malować i zainteresował się fotografią. Na swój pierwszy aparat fotograficzny zarobił, oddając krew ${ }^{10}$. Wówczas ukształtował się jego zmysł estetyczny, który później miał znaleźć wyraz w wizualnej soczystości, znaku rozpoznawczym twórczości reżysera.

W celu pobierania nauk od proletariatu i chłopstwa na prowincję przesiedlono w sumie około 20 mln Chińczyków z miast ${ }^{11}$, w przeważającej większości studentów i uczniów szkół średnich, w tym Chena Kaige i Tiana Zhuangzhuanga, którzy mieli wraz z Zhangiem Yimou stanowić w przyszłości trzy filary nowego pokolenia filmowców. Tymczasem przez cały ponad dziesięcioletni okres trwania rewolucji instytucje kultury praktycznie nie funkcjonowały - z pominięciem sztuki rewolucyjnej. „W pięcioleciu 1967-1972 w ChRL nie powstał ani jeden film fabularny (...). Doszczętnie zniszczono tradycyjną operę i teatr" ${ }^{\prime 2}$. Również prestiżowa Akademia Filmowa w Pekinie, przyszła Alma Mater piątej generacji, nie prowadziła w latach 1966-1976 działalności edukacyjnej.

Rewolucja kulturalna miała niszczący wpływ na prawie każdy aspekt życia mieszkańców Chin. Choć intencje jej autorów były zgoła inne, doprowadzony do moralnej ruiny kraj otworzył się na transformację gospodarki i społeczeństwa w duchu kapitalistycznym.

6 Ibidem, s. 714.

7 Zob. J.R. Jones, Zhang Yimou returns to the bad old days of the Cultural Revolution, „Chicago Reader”, 26.09.2015, https://www.chicagoreader.com/chicago/coming-home-zhang-yimou-gong-li-daoming-chen-cultural-revolution-china/Content?oid=19254279 (dostęp: 10.01.2020).

8 Zob. A. Helman, Zhang Yimou: wszystkie odcienie czerwieni [w:] Autorsy kina arjatyckiego, red. A Helman, A. Klamrowska, Kraków 2010, s. 40.

9 Zob. A. Helman, Wiejskie kino..., s. 23.

10 Zob. Zhang Yimou Biography [w:] Encyclopedia of World Biography, https://www.notablebiographies.com/supp/Supplement-Sp-Z/Zhang-Yimou.html (dostęp: 10.01.2020).

11 Zob. W. Rodziński, Historia..., s. 713.

12 J. Polit, Chiny..., s. 257-258. 


\section{Piąta generacja kina chińskiego}

Zapoczątkowana przez Denga Xiaopinga transformacja przyniosła Chińczykom realna perspektywę przyszłego dobrobytu. Jednocześnie, wraz z odejściem od polityki gospodarczej Mao Zedonga, nastapił odwrót od surowych ideałów rewolucji kulturalnej. W pewnym sensie 2 lata po zakończeniu jednej rozpoczęła się kolejna rewolucja, która tym razem miała niewiele wspólnego z wizją Wielkiego Sternika. Deng Xiaoping przystapił do reformowania zrujnowanego kraju, stosując środki zapożyczone z ideologii znienawidzonego przez zagorzałych komunistów Zachodu. Liberalizacji gospodarki towarzyszyła zmiana mentalności obywateli Chin, zwłaszcza mieszkańców miast, wynikająca z większej dostępności towarów i ograniczenia ingerencji państwa w życie jednostki. „Po latach zaczął wracać konsumpcjonizm. (...) W miastach nastąpiła rewolucja obyczajowa. (...) Dziewczyny wskoczyły w szpilki, modne spódniczki, kręciły włosy w loki i nosiły makijaż. (...) Nawet przedstawiciele Chińskiej Armii Ludowo-Wyzwoleńczej (...) wystroili się $\mathrm{w}$ mundury galowe $\mathrm{z}$ licznymi złotymi szamerunkami. (...) W stolicy pobrzmiewały zachodnie rytmy, przebojowe melodie z Tajwanu czy Hongkongu, płynące z kieszonkowych odbiorników radiowych czy przenośnych radiomagnetofonów"13.

Dla Zhanga Yimou i innych przyszłych reżyserów z pokolenia „dzieci Mao” fala liberalizacji oznaczała długo wyczekiwaną szansę na rozwój swoich ambicji artystycznych. Prestiżowa Akademia Filmowa w Pekinie po raz ostatni przed rewolucja przyjęła nowych studentów w 1965 r. ${ }^{14} \mathrm{~W} 1978$ r. wznowiła jednak działalność, a 4 lata później pierwszy porewolucyjny rocznik zakończył naukę i stał się trzonem piątej generacji kina chińskiego, mając w swoich szeregach tak wybitnych filmowców, jak Zhang Yimou, Chen Kaige, Tian Zhuangzhuang oraz Zhang Junzhao. Znakiem rozpoznawczym ich twórczości stał się „nowy język filmowy, łączący tradycje chińskie z europejskim modernizmem"15.

By zobrazować sytuację, w jakiej znaleźli się absolwenci pierwszego porewolucyjnego rocznika Akademii Filmowej w Pekinie, warto przytoczyć scenę z jednego z najodważniejszych politycznie filmów Zhanga Yimou - Żyć! (Huozhe, 1994). Główny bohater zarabia na życie, organizując spektakle teatru marionetek. Figurki przedstawiaja postaci z dziejów Chin cesarskich, dlatego w czasie

13 J. Fenby, Chiny: upadek i narodžiny wielkiej potęgi, tłum. J. Wąsiński, J. Wołk-Laniewski, Kraków 2009 , s. 739.

14 Zob. D. Garrett, Memoirs from the Beijing Film Academy. International Cinema, Chen Kaige and Zhang Yimou's school days, „Offscreen” 2006, vol. 10, issue 8, http://offscreen.com/view/beijing film_academy (dostęp: 10.11.2019).

15 A. Wycisk, Między sžtuka a politykeq: kino chińskie, kino bongkońskie, „Pisma Humanistyczne” 2013, z. 9, s. 287, http://www.pismahumanistyczne-wns.us.edu.pl/doc/IX.pdf (dostęp: 10.11.2019). 
rewolucji kulturalnej zostają spalone na rozkaz czerwonogwardzistów. Ten „dramatyczny akcent zniszczenia marionetek jest znakiem zagłady dawnego porządku, tradycji, kultury, symbolem przekreślenia całej przeszłości"16. I nawet jeżeli rewolucjonistom nie udało się doprowadzić dzieła zagłady do końca, to stworzyła się wskutek ich działań swego rodzaju kulturowa próżnia, która sprzyjała nowym początkom.

Ważnym źródłem inspiracji dla młodych twórców stało się kino europejskie i amerykańskie, z którym autorzy piątej generacji zetknęli się po raz pierwszy w Akademii Filmowej. Dla wielu z nich stanowiło to szok kulturowy - dotąd znali przede wszystkim kino rodzime, które po 1949 r. zostało całkowicie podporządkowane tematyce politycznej. Chen Kaige w dokumencie Kino chinskie wczoraj $i$ dzis (Le cinema chinois, hier et aujourd'bui, 2007) opowiada o tym, jak dopiero zapoznanie się z kinem zachodnim uzmysłowiło reżyserom piątej generacji, że „kino to medium swobodnego wyrazu"17, które nie musi być podporządkowane celom propagandowym. W połączeniu z bolesnymi doświadczeniami rewolucji kulturalnej (za najbardziej skrajny przykład mógłby posłużyć Chen Kaige, który wyniósł z tego okresu poniżające doświadczenie denuncjacji własnego ojca ${ }^{18}$ ) zrodziło to niechęć do otwartego upolityczniania sztuki, odróżniającą twórczość piątego pokolenia od całej wcześniejszej kinematografii chińskiej doby komunizmu.

Obok Akademii Filmowej w Pekinie ważnym dla młodych twórców ośrodkiem stało się państwowe Studio Filmowe w Xi’an. Kluczową postacią środowiska był Wu Tianiming - urodzony w 1939 r. filmowiec, którego karierę aktorską przerwała rewolucja kulturalna. Po jej zakończeniu przeszedł kurs reżyserski na Akademii Filmowej w Pekinie, po czym wrócił do Xi’an, gdzie ponownie związał się z tamtejszym Studiem Filmowym, tym razem poświęcając się pracy reżyserskiej. W 1983 r. został mianowany dyrektorem studia, co dało mu możliwość wpływania na twórczość młodych filmowców nowego pokolenia ${ }^{19}$. Geniusz Wu polegał na prowadzeniu działalności dwutorowo - z jednej strony angażował się w komercyjne projekty (shangye pian), cieszące się dużą popularnością wśród widzów i przynoszące realne zyski; z drugiej - zarobione w ten sposób pieniądze przeznaczał na dofinansowanie projektów artystycznych (tansuo pian), w ramach których forsował tworzenie kina eksperymentalnego, bez oglądania się na jego potencjał komercyjny. Od połowy lat 80. do początku 90. najważniejsi reżyserzy młodego pokolenia intensywnie współpracowali z Wu ${ }^{20}$, czego owocem były takie arcydzieła kina chińskiego, jak Złodziej

16 A. Helman, Zhang Yimou..., s. 47.

17 Kino chinskie wczoraj i dziś (Le cinema chinois, bier et aujourd'bui), reż. H. Niogret, 2007.

18 Zob. L. Klady, Interview with Chen Kaige, MCN, 31.05.2003, https://web.archive.org/web/ 20070401033940/http://www.moviecitynews.com/Interviews/kaige.html (dostęp: 10.11.2019).

19 Zob. Zh. Xiao, Y. Zhang, Encyclopedia of Chinese Film, London 2002.

20 Zob. Y. Xiao, China in the Mix: Cinema, Sound, and Popular Culture in the Age of Globalization, Mississippi 2017. 
koni (Daomazei, reż. Tian Zhuangzhuang, 1986), Król džieci (Haiz̨i wang, reż. Chen Kaige, 1987), Cžrwone sorgo (Hong gaoliang, reż. Zhang Yimou, 1988) czy Ju Dou (reż. Zhang Yimou, 1990).

\section{Niezależny twórca, niezależni bohaterowie - cykl kobiecy}

Tak przedstawiały się okoliczności powstania piątej generacji kina chińskiego. Zhang Yimou szybko wyrósł na jedną z czołowych postaci nowej fali. Na Akademię Filmowa w Pekinie dostał się mimo przekroczenia limitu wiekowego - uczelniani decydenci zrobili dla Zhanga wyjątek po obejrzeniu jego prac fotograficznych ${ }^{21}$. Właściwa kariera w branży filmowej zaczęła się od pracy na stanowisku kierownika zdjęć w takich obrazach, jak uznawany za pierwsze dzieło całej generacji Jeden $i$ osiem $^{22}$ (Yige he bage, reż. Zhang Junzhao, 1983), przełomowa dla kinematografii chińskiej Żótta riemia (Huang tu di, reż. Chen Kaige, 1984) czy Stara studnia ${ }^{23}$ (Lao jing, 1986) w reżyserii guru piątej generacji, Wu Tianminga, w którym to filmie obok wykonywania pracy operatorskiej zagrał też główną rolę aktorską.

Jako reżyser Zhang zadebiutował w 1987 r. ekranizacją powieści późniejszego noblisty Mo Yana - filmem Czerwone sorgo (Hong gaoliang). Jest to zarazem początek cyklu obrazów, w których motyw indywidualnego buntu i poszukiwania własnej drogi - na przekór obowiązującym normom obyczajowym, z pogwałceniem zasad społecznych i prawa - będzie się przeplatać $z$ biegunowo przeciwną ideą podporządkowania władzy i wspólnocie, kosztem własnych potrzeb i pragnień jednostki. Punktem wyjścia we wspomnianym filmie jest aranżowane małżeństwo głównej bohaterki Jiu’Er ze starym właścicielem destylarni wina, o którym krążą plotki, że jest trędowaty. Zgodnie z patriarchalną tradycja Jiu’er „musi być posłuszna jako córka i poślubić trędowatego mężczyznę" ${ }^{24}$, za co ojciec bohaterki otrzyma w zamian muła. Małżeństwo nie trwa jednak długo, właściciel destylarni umiera w tajemniczych okolicznościach, prawdopodobnie zamordowany przez Yu Zhan'ao, kochanka Jiu'er - film pozostawia to w sferze niedomówien, książka natomiast stwierdza jednoznacznie. Po śmierci męża bohaterka zgodnie z tradycją powinna pozostać wdowa do końca życia, łamie jednak tabu społeczne, przyjmuje Yu Zhan’ao pod swój dach i rodzi ich wspólne dziecko. Byłby to zatem przykład udanego buntu i triumfu indywidualności, gdyby nie fakt, że Jiu’er ostatecznie ginie z rąk japońskich najeźdźców, przeciwko którym wystąpiła wraz z pracownikami destylarni.

\footnotetext{
21 Zob. Zhang Yimou Biography...

22 Tytuł filmu w tłumaczeniu własnym.

23 Tytuł filmu w tłumaczeniu własnym.

24 A. Helman, Zhang Yimou..., s. 53.
} 
W kolejnym dramacie, Ju Dou (1990), ponownie bohaterka zostaje za pieniądze wydana za mąż, zmuszona do małżeństwa z despotycznym właścicielem farbiarni tkanin, bezpłodnym Jinshanem. W domu męża poznaje jego adoptowanego siostrzeńca - Tianqinga. Bohaterowie nawiązują romans, którego owocem jest dziecko - Tianbai. Istotny jednak jest tu przede wszystkim niewidoczny na pierwszy rzut oka, a jednocześnie niezbędny dla zrozumienia filmu bezosobowy bohater, tj. relacje społeczne. „Los kochanków determinuje (...) Prawo, które działa niezmiennie, bez względu na okoliczności i siłę uczuć łączących zakochanych"25. W odróżnieniu od Czerwonego sorga próba indywidualnego buntu kończy się w Ju Dou jednoznacznym niepowodzeniem - mimo śmierci despoty kochanek zostaje oddalony, a tytułowa bohaterka skazana na samotne życie wdowy. Kropką nad i jest postawa Tianbaia, kilkuletniego już chłopca, który staje się ucieleśnieniem prawa, gdy na przekór prawdzie uznaje zmarłego despotę za swojego ojca, a matkę nienawidzi za zdradę. W ostatecznym rozrachunku racja wspólnoty okazuje się silniejsza od woli jednostki.

Podobnie tragiczny los staje się udziałem bohaterki Zawieście çerwone latarnie (Da Hong Denglong Gaogao Gua, 1991). Songlian zostaje czwartą nałożnica kolejnego filmowego patriarchy, człowieka, którego „twarzy nigdy nie widzimy wyraźnie. (...) Słyszymy tylko jego głos, zimny i niski. Poprzez uczynienie patriarchy niewidocznym Zhang nie sprawia, że jest on nieobecny, a właśnie wszechobecny pod postacia czystego nadzoru i władczego spojrzenia" ${ }^{26}$. W filmie nie poznajemy nawet imienia głowy domu. Patriarcha stanowi niemalże bezosobowe ucieleśnienie odwiecznego prawa, a sam dom sprawia wrażenie więzienia. Rola Songlian sprowadza się do zapewniania rozrywki „mistrzowi” i podtrzymywania nadziei na męskiego potomka. Jednak w odróżnieniu od obu wcześniej przytoczonych obrazów bohaterka Zawieście czerwone latarnie nie próbuje się buntować, wręcz przeciwnie aktywnie zabiega o względy patriarchy, włączając się w rywalizację z pozostałymi konkubinami. Toksyczna atmosfera domostwa doprowadza ją ostatecznie do załamania nerwowego i szaleństwa.

W przedstawionym tryptyku filmowym widzimy pewną ewolucję postaw. Jiu'er z Czerwonego sorga ucieleśnia otwarty bunt, ,jest od początku do końca kobieta, która sama stanowi o swoim losie, nieugiętą wobec przeciwieństw"27. To postawa charakterystyczna dla „dzikich i beztroskich dni”"28 drugiej połowy lat 80., kiedy

\footnotetext{
25 Ibidem, s. 62.

26 „we never see his face clearly. (...) We only hear his voice, cold and flat. By making the patriarch invisible, Zhang is not making him absent, but omnipresent as a pure watching and commanding "gaze«", L. Qin, Transmedia strategies of appriopration and visualization: The case of Zhang Yimou's adaptation of novels in his early films [w:] Art, politics, and commerce..., s. 168.

27 A. Helman, Zhang Yimou..., s. 52.

28 Y. Li, Lou Ye, The Birth of a Personal Eye, Hong Kong 2010, s. 131, cyt. za: A. Mikrut-Żaczkiewicz, Lou Ye: szukajac to:̇samości [w:] Autorzy kina azjatyckiego II, red. A. Helman, A. Kamrowska, Kraków 2015.
} 
fala liberalizacji życia politycznego wzbierała, a inteligencja otwarcie domagała się demokratyzacji państwa. Jak wiadomo, ruch prodemokratyczny osiagnął swój punkt kulminacyjny w protestach studenckich, stłumionych krwawo w czerwcu 1989 r. „Elity kulturalne powstrzymano przed publicznym wystapieniem, a zatem legalność ich istnienia została zakwestionowana. W tym czasie we wszystkich dziedzinach kultury podjęto krytykę rządu"29. Także w filmach Zhanga Yimou można dopatrzeć się wyraźnego wzrostu poziomu pesymizmu. Ju Dou buntuje się już tylko w zaciszu domowym, wykorzystując kalectwo patriarchy, nie znajduje jednak odwagi, by otwarcie przeciwstawić się tradycji i wspólnotowej starszyźnie. W Zawieście czerwone latarnie studentka Songlian, pozbawiona środków finansowych po śmierci ojca, sama decyduje się na los konkubiny, nie widząc przed sobą perspektyw na życie według własnych potrzeb i upodobań. „Czyż nie taki jest los kobiety?" - pyta retorycznie matkę. Rzeczywiście, kobieta w tradycyjnym społeczeństwie nie miała możliwości decydowania o własnym losie, zwykle przeznaczano ją z góry do jednej z pięciu podstawowych ról: żony, konkubiny, służącej, niańki albo prostytutki ${ }^{30}$.

Powracający motyw uciskanej kobiety w filmach Zhanga Yimou można rozpatrywać nie tylko jako dosłowny portret Chin dawnych, lecz także jako alegorię czasów reżyserowi współczesnych. „Kobieta, którą od wieku ciemiężył wielowymiarowo opresyjny system społeczny i obyczajowy, zaczęła funkcjonować w literaturze i filmie chińskim na prawach figury odzwierciedlającej wielowiekową niedolę chińskiego narodu"31. Wprawdzie twórcy piątej generacji unikali otwartej polityzacji swojej twórczości, jednak komentowali rzeczywistość z zachowaniem „aluzyjnego dystansu" ${ }^{2}$, tj. posługując się wieloznacznością charakterystyczną dla całej kultury chińskiej. Z jednej strony podyktowane to było koniecznością, bowiem mimo pewnego zelżenia kontroli państwa nad obywatelami nadal funkcjonowała cenzura; z drugiej zaś umożliwiało tworzenie dzieł wielowymiarowych, nieograniczających się tylko do bieżącego komentarza politycznego czy społecznego.

W świetle powyższych rozważań wydaje się uzasadnione takie odczytanie pierwszych obrazów Zhanga, zgodnie z którym sytuacja bohaterek dramatów historycznych odzwierciedla sytuację jednostki także we współczesnych reżyserowi Chinach komunistycznych. Atmosfera swobody charakterystyczna dla lat 80. wyraźnie znajduje odzwierciedlenie w Cžerwonym sorgu. Z kolei powszechne wśród elit poczucie rezygnacji po stłumieniu protestów na placu Tiananmen koresponduje z głębokim

29 A. Mikrut-Żaczkiewicz, Jia Zhangke: Mali ludzie w czasach wielkiej żmiany [w:] Autorzy kina arjatyckiego, red. A. Helman, A. Kamrowska, Kraków 2010, s. 13.

30 Zob. N. Dougherty, Prostitution in contemporary China. The case of Shanghai Jiading, Shanghai 2006, s. 5, http://www.24grammata.com/wp-content/uploads/2014/08/Prostitution_in_China.pdf (dostęp: 10.11.2019).

31 A. Helman, Zhang Yimou..., s. 59.

32 Zob. ibidem, s. 56. 
pesymizmem Ju Dou i w szczególności Zawieście czerwone latarnie. Taką interpretację zdaje się również potwierdzać fakt, że oba filmy zostały początkowo zakazane przez cenzurę ${ }^{33}$, mimo że pokazano w nich przecież porządek społeczny Chin cesarskich, którego krytyka powinna być komunistycznym władzom na rękę. Najwyraźniej uwadze cenzorów nie uszła dwuznaczność obrazów, skrywana pod płaszczykiem dramatu historycznego.

\section{W stronę komunizmu, w stronę konformizmu - cykl zwykłych ludzi}

Akcja kolejnych dwóch dzieł Zhanga toczy się już w komunistycznych Chinach. W Historii Qiu Ju (Qiu Ju da guan si, reż. Zhang Yimou, 1992) mamy do czynienia z jeszcze jedną wyrazistą postacią kobieca. Tytułowa bohaterka, prosta chłopka wyrusza do miasta, by walczyć o sprawiedliwość dla poniżonego przez partyjnego urzędnika męża. Film ten ,jest modelową opowieścią o relacji jednostka - system, w której jednostka z góry skazana jest na przegraną"34. Warto jednak podkreślić, że Qiu Ju nie buntuje się przeciwko systemowi jako takiemu, lecz raczej szuka sprawiedliwości w jego granicach, zwracając się ze swoją skargą do kolejnych szczebli machiny urzędniczej. Nawet jeżeli punktem wyjścia jest krytyka władz komunistycznych, to summa summarum ich obraz w filmie jest pozytywny - urzędnicy podchodza do sprawy Qiu Ju ze zrozumieniem, a sam winowajca okazuje się w ostatecznym rozrachunku przyzwoitym człowiekiem. Niewykluczone, że to właśnie ów łagodny ton Historii Qiu Ju zapewnił Zhangowi przychylność cenzury, która po premierze filmu zezwoliła również na krajową dystrybucję dwóch wcześniej zakazanych dzieł Ju Dou i Zawieście czerwone latarnie ${ }^{35}$.

$\mathrm{Na}$ czarną listę trafił za to dramat Żyó! (Huoz̧he, 1994), w którym Zhang po raz pierwszy podejmuje próbę rozliczenia epoki maoizmu; próbę raczej subtelna, stonowana, omijająca zupełnie niektóre dramatyczne epizody (wielki głód), a traktująca z przymrużeniem oka inne (rewolucja kulturalna). Lżejszy ton nie oznacza jednak, że reżyser podchodzi do tematu niepoważnie. Jest to kolejny przykład „aluzyjnego dystansu" i wymaga właściwego, pogłębionego odczytania. Główny bohater, jak pisze Alicja Helman, „konformistycznie nastawiony Fugui robi wszystko, aby przeżyć”36. Wydaje się, że okoliczności zewnętrzne mają do niego dostęp tylko o tyle, o ile wymagają zmiany strategii przetrwania. Fakt, że przegranie rodzinnego majątku w kasynie pozwoliło mu uniknąć czystek w czasach Mao, wywołuje w nim jedy-

\footnotetext{
33 Zob. F. Gateward, Y. Zhang, Zhang Yimou: Interviews, Mississippi 2001, s. 30.

34 A. Helman, Zhang Yimou..., s. 63.

35 Zob. F. Gateward, Y. Zhang, Zhang Yimou..., s. 31.

36 A. Helman, Zhang Yimou ..., s. 54.
} 
nie niejasne poczucie dziwności istnienia, ale nie skłania do głębszej refleksji. Fugui nie oponuje także, gdy otrzymuje rozkaz spalenia marionetek teatru cieni - przez wiele lat będących dla niego jedynym źródła utrzymania. „Gdy znikają marionetki, następuje inwazja czerwieni”, w tym przypadku będącej „symbolem wszechwładzy i wszechobecności reżimu komunistycznego, który podporządkowuje swoim dyrektywom wszystkie sfery życia obywateli" ${ }^{37}$. Dla Fugui'a nie stanowi to jednak problemu. Helman podsumowuje go jako typowego Chińczyka „czasów, w których przyszło mu żyć, kiedy tym, co jedynie mógł ocalić, było samo życie”38. Pesymistyczny pogląd na sytuację jednostki w społeczeństwie chińskim osiaga w tym momencie apogeum. W kolejnym dramacie historycznym, Szanghajskiej triadzie (Yao a Yao, Yao Dao Waipo Qiao, 1995), „powtarzającym się motywem werbalnym jest fraza »takie są zasady«. (...) »Zasady« decydują o życiu i śmierci, która jest definitywnym sposobem porachunku z nieposłusznymi i niepodporządkowanymi" 39 . Film opowiada o mafii w czasach przedrewolucyjnych, jednak jego treść osadzona w szerszym kontekście wcześniejszych dzieł reżysera znowu pozostawia szerokie pole do interpretacji.

Po Szanghajskiej triadzie motyw konfliktu jednostki z władzą zanika, a kolejne obrazy cechuje lżejsza, niemal rozrywkowa tonacja. "Zhang zamienił nowofalowa elitarność wczesnej piątej generacji w elegancki nowy populizm" ${ }^{40}$, przenosząc środek ciężkości na życie i problemy zwykłych ludzi w Chinach czasów transformacji. Zachowaj spokój (You Hua Hao Hao Shuo, 1997) i Szçeście na raty (Xingfu shiguang, 2000) to obrazy satyryczne, komentujące z przymrużeniem oka konsumpcjonizm nowego, bogacącego się społeczeństwa miejskiego. Dramat Ws systko albo nic (Yi ge dou bu neng shao, 1999) poprzez uczynienie bohaterami dzieci z biednej prowincji podejmuje próbę zwrócenia uwagi na problem pogłębiających się nierówności społecznych. Z kolei Droga do domu (Wo de fuqin muqin, 1999) to nostalgiczne spojrzenie na świat dawnych relacji międzyludzkich i sielankowa wizja wiejskiego życia, nienaznaczonego jeszcze piętnem materializmu i industrializmu epoki transformacji.

Zmianę tematyki ponownie można wytłumaczyć zmianą sytuacji polityczno-społecznej. Po zdławieniu demokratycznego zrywu lat 80. przywódcy partyjni szukali uzasadnienia dla autorytarnych rządów w wysokim wzroście gospodarczym i wynikającym z niego dobrobycie. „W czasach Mao w ludziach podsycano zapał rewolucyjny, a (...) w latach dziewięćdziesiątych cały naród wpadł w obsesję na punkcie zarabiania pieniędzy. Nie liczyło się właściwie nic innego" "41. By lepiej zrozumieć fenomen tej metamorfozy, warto cofnąc się do postaci Fugui’a z Żyć!,

37 Ibidem, s. 47.

38 Ibidem, s. 55.

39 Ibidem, s. 48.

40 „Zhang transformed the early Fifth Generation's New Wave elitism into a stylish new populism", Y. Zhu, B. Robinson, The Cinematic Transition..., s. 152.

41 P. Ho, W. Huang, Uderzenie w czerń. Morderstwo, pieniadze i walka o władze w Chinach, tłum. D. Cieśla-Szymańska, Wołowiec 2015, s. 363. 
konformisty totalnego i reprezentanta całego „straconego pokolenia” Chińczyków. Wybitny reporter i znawca Chin Tiziano Terzani widział w konformistycznym podejściu mieszkańców Państwa Środka do rzeczywistości świadomą strategię. „Chińczycy znów praktykują swoją wielką sztukę - sztukę przetrwania” - pisał o sytuacji w Chinach po masakrze na placu Tiananmen. „Aby przetrwać, należy zakamuflować się w anonimowym tłumie" ${ }^{\prime 2}$. W latach 90 . reformy wolnorynkowe poskutkowały przywróceniem gospodarce normalności, dzięki czemu przedsiębiorczy z natury Chińczycy mogli poświęcić się budowie materialnego dobrobytu. „Kamuflaż” okazał się niepotrzebny, wystarczył charakterystyczny dla mieszkańców Państwa Środka pragmatyzm, co również znalazło swoje odzwierciedlenie w twórczości Zhanga Yimou.

Warto przy tym zwrócić uwagę, że choć w owym okresie w jego filmach motyw konfliktu jednostki z władzą stopniowo zanika, to nie zastępuje go bezkrytyczna akceptacja nowej chińskiej rzeczywistości lat 90. Zwłaszcza Historia Qiu Ju i Wsayscy albo niket zawierają wyraźny komentarz społeczny, biorący na celownik negatywne zjawiska epoki transformacji - rozrost machiny biurokratycznej, kult pieniądza, problem nierównomiernego wzrostu gospodarczego w mieście i na prowincji czy zacofany system edukacji na wsi. Nawet komediowe Zachowaj spokój i Szcześćie na raty uderzają w konsumpcjonizm i materializm nowej mieszczańskiej klasy średniej, a Droga do domu zderza ponury, industrialny krajobraz lat 90. z idylliczną wiejska przeszłością, wyraźnie umiejscawiając sympatię reżysera po stronie tej drugiej.

\section{W stronę komercji, w stronę koniunkturalizmu - cykl wuxia}

Złagodzenie tonu, charakterystyczne dla twórczości Zhanga Yimou zwłaszcza w drugiej połowie lat 90., miało okazać się zaledwie zapowiedzią późniejszej większej przemiany reżysera w duchu nowej epoki. W 2002 r. na ekrany kin wszedł film Hero (Yinxiong). Zhang Yimou po raz pierwszy w swojej karierze nakręcił obraz z popularnego w Azji gatunku wuxia ${ }^{43}$. Akcja rozgrywa się w 227 r. p.n.e., w okresie rozbicia dzielnicowego Chin, zwanego epoką Walczących Królestw. Osią fabuły jest zamach na życie króla państwa Qin, przyszłego pierwszego cesarza zjednoczonego Cesarstwa Chińskiego, władcy, który zasłynął szczególnym okrucieństwem, zarówno w okresie walk o dominację nad całym krajem, jak i po ich zakończeniu.

42 T. Terzani, $W$ Azji, Warszawa 1998.

43 Utwory z gatunku wuxia cechuje skupienie fabuły wokół tradycyjnych sztuk walki, bohaterami są zwykle ich mistrzowie. Więcej na temat: Martial arts as embodied knowledge. Asian traditions in a transnational world, eds. D.S. Farrera, J. Whalen-Bridge, New York 2011; S. Teo, The martial arts film in Chinese cinema [w:] Arts, politics and commerce in Chinese cinema, eds. Y. Zhu, S. Rosen, Hong Kong 2010; W. Ghermani, Kino wuxia: poerja sztuk walki, „Kino” 2015, nr 11. 
Ościenne królestwa, w obawie przed nieuchronną inwazją, planują spisek na życie tyrana. Główny bohater, bezimienny mistrz miecza, dociera przed oblicze władcy, zdobywa jego zaufanie i staje przed szansą wypełnienia misji. Do tego momentu historia opowiedziana w filmie pokrywa się z wydarzeniami opisanymi przez Sima Qiana, historyka dynastii Han zwanego „chińskim Herodotem”. Jednak zgodnie z relacją uczonego zamachowiec, Jing Ke, przypłacił życiem nieudaną próbę zasztyletowania króla. W odpowiedzi na zamach państwo Qin krwawo rozliczyło się ze spiskującymi sąsiadami, zwłaszcza z państwem Yan, zajmując całe jego terytorium i unicestwiając rządząca nim dynastię ${ }^{44}$. W filmie natomiast główny bohater wdaje się z przyszłym cesarzem w dyskusję i koniec końców składa broń, uznając argument o słuszności brutalnych działań na rzecz zjednoczenia kraju. Następnie zostaje stracony, a władca urządza mu pochówek z żołnierskimi honorami, czyniąc z nawróconego w ostatnim momencie awanturnika symbol triumfu interesu państwa nad sentymentami jednostki.

W Hero Zhang Yimou powraca zatem do problemu jednostkowego buntu i opresyjnej władzy, wydźwięk filmu jest jednak zupełnie inny niż wcześniejszych dramatów historycznych reżysera. W Czerwonym sorgu, Ju Dou, Zawieście czerwone latarnie czy Szanghajskiej triadzie reżyser sympatyzował z jednostką, kładąc akcent na tragizm i niesprawiedliwość jej nieuchronnej porażki. W Hero jednostka zrzeka się prawa do stanowienia o własnym losie i uznaje wyższość racji stanu. Na dodatek dzieje się tak wskutek przeinaczenia tekstu klasycznego dzieła chińskiej historiografii. Odwołanie się w filmie do kontrowersyjnej postaci pierwszego cesarza z pominięciem ciemnej strony jego historii - za to z wyraźną aprobatą dla „rządów silnej ręki” - zwiastuje wyraźną zmianę w sposobie myślenia reżysera. Jednocześnie obraz ów to pierwsza wysokobudżetowa produkcja Zhanga i pierwszy sukces kasowy nie tylko na krajowym rynku, ale i na skalę światową (po swojej premierze w USA w 2004 r. przez dwa tygodnie znajdował się na szczycie amerykańskiego box-office $e^{45}$. Nie powinno zatem dziwić, że Hero wywołał burzliwą dyskusję i sprowokował zarzuty o „sprzedanie się”, zarówno w sensie artystycznym jak i ideologicznym ${ }^{46}$, zwłaszcza ze strony zachodnich krytyków.

Argumentów za dostarczaja dwa kolejne filmy spod znaku wuxia. Dom latajacych sztyletón (Shi Mian Mai Fu, 2004) to obraz, w którym miejsce konfliktu jednostki z władzą zajmuje historia miłosna. Trudno doszukiwać się w nim tak charakterystycznej dla wcześniejszych filmów reżysera wieloznaczności. Prostota przekazu

${ }^{44}$ Zob. Y Pines, A Hero Terrorist: Adoration of Jing Ke Revisited, „Asia Major” 2008, vol. 21, no. 2, $3^{\text {rd }}$ series, https://www.jstor.org/stable/41649954 (dostęp: 10.11.2019).

45 G.A. Johnson, Worldwide, Asian films are grossing millions. Here, they're either remade, held hostage or released with little fanfare, „San Francisco Chronicle”, 3.02.2005, https://web.archive.org/ web/20120901100246/http://www.sfgate.com/entertainment/article/VIEW-WorldwideAsian-films-are-grossing-2733592.php (dostęp: 10.21.2019).

46 Zob. Y. Zhu, B. Robinson, The Cinematic Transition... 
w połączeniu z widowiskowością i sukcesem kasowym przyczyniła się do wzmocnienia tezy, że „dawny twórca awangardowy przeszedł na pozycje kina komercyjnego" ${ }^{47}$. Natomiast Cesarzowa (Mancheng Jindai Huangjinjia, 2006) wsparła dodatkowo zarzut, że twórczość Zhanga Yimou zaczęła charakteryzować „faszystowska tematyka $i$ orientacja na estetykę" ${ }^{48}$. W filmie tym problematyka silnej scentralizowanej władzy powraca za sprawą osadzenia akcji na dworze cesarskim dynastii Tang w epoce tzw. Pięciu Dynastii i Dziesięciu Królestw, czyli - podobnie jak w przypadku Hero - w okresie rozbicia dzielnicowego Chin.

Z okazji święta narodowego w pałacu zbiera się cała rodzina cesarska. Na jej łonie rozgrywa się dramat, w którym kluczową rolę odgrywa nie tyle tytułowa cesarzowa ${ }^{49}$, ile ucieleśniona w osobie jej męża władza absolutna. „Niebo dyktuje prawa, według których żyjemy na Ziemi. Każdy zajmuje miejsce, które mu wyznaczono" - słyszymy z ust cesarza Tang. Ponieważ władca jest reprezentantem Nieba, prawa podyktowane przez Niebo można uznać za tożsame ze słowem i wola władcy. Potwierdzenie takiej interpretacji odnajdujemy w rozmowie monarchy z synem, w której poucza go słowami: „Mnóstwo jest rzeczy na Ziemi i w Niebie, ale możesz mieć tylko te, które ja zdecyduję się ci ofiarować". I rzeczywiście: na dworze wszystko podporządkowane jest jego woli, włącznie ze szczęściem najbliższych. Wszelkie próby protestu kończą się druzgocącą klęską. Szczególnie sugestywnie oddziałuje na widza scena, w której służba pałacowa ściera z placu przed pałacem krew po wymordowanych uczestnikach buntu.

\section{Od awangardy do apologii władzy totalitarnej?}

Czy zatem Zhang Yimou rzeczywiście stał się w XXI wieku piewcą rządów silnej ręki i stronnikiem władzy komunistycznej, której ofiarą sam padł przecież w czasach rewolucji kulturalnej? Argumentem za wydaje się powierzenie mu roli reżysera ceremonii otwarcia olimpiady w Pekinie w 2008 r. Sam Zhang zawsze utrzymywał, że jest twórcą apolitycznym, jednak trudno wyobrazić sobie, żeby w komunistycznych Chinach taki zaszczyt mógł spotkać artystę niecieszącego się zaufaniem władz. Warto również zwrócić uwagę na głosy ze strony innych filmowców, zwłaszcza politycznych kontestatorów z szóstego pokolenia chińskich reżyserów. Jak zauważył Wang Chao, komentując omawiane obrazy, ,jedno z niebezpieczeństw grożących kinu piątej generacji polega na tym, że pragną w swoich filmach udowodnić, iż te

\footnotetext{
47 A. Helman, Zhang Yimou..., s. 67.

48 „fascist thematic and aesthetic orientations”, Y. Zhu, B. Robinson, The Cinematic Transition..., s. 152.

49 Warto pamiętać o tym, że polski tytuł nie ma nic wspólnego z tytułem oryginalnym, który nie odnosi się bezpośrednio do żadnego z bohaterów filmu.
} 
kłamstwa [komunistów w czasach Mao] miały swoista celowość historyczną. Nie wolno nam w to uwierzyć. (...) Należy zabiegać o obiektywne ukazanie rzeczywistości. Te problemy zostały przedstawione w filmach Zhanga Yimou i Chena Kaige: Hero oraz Prayssiega. Zachodzi obawa, że z punktu widzenia indywidualnej oceny twórcy ci przedstawiają fałszywy obraz historiii" ${ }^{\prime 50}$.

Światopogląd twórców szóstego pokolenia ukształtowały liberalne lata 80., w szczególności zaś ich dramatyczny finał w postaci masakry na placu Tiananmen, która „ukształtowała wyobraźnię i pozostała niezaleczoną raną całej generacji1" ${ }^{\text {"1. }}$. Rezultatem owych doświadczeń jest głęboka wrażliwość społeczna i polityczna cechująca nowych filmowców, stąd nie powinno dziwić, że Wang Chao dostrzega w filmach swoich starszych kolegów wymiar propagandowy i obawia się konsekwencji uprawiania polityki historycznej na ekranie.

Głosy w obronie reżysera zwykle odwołują się bądź to do przejawiającej się w Hero, Domu latajacych satyletón i Cesarzowej orientacji na warsztat i estetykę jako głównego bodźca stojącego za powstaniem obrazów, bądź też szukają uzasadnienia dla kontrowersyjnych treści w specyfice chińskiej kultury, powołując się na jej kolektywny, wywodzący się z konfucjanizmu charakter. W pierwszym przypadku warto przytoczyć słowa Alicji Helman, wedle której „w tych filmach interesowały go (...) nie tyle treści czy dramaty ludzkie, co przede wszystkim problemy natury warsztatowej i technicznej" 52 . Pojawia się również sugestia, że zwrot w stronę kina wuxia to przypadek analogiczny do Piratón (Pirates, 1986) Polańskiego, kiedy to „twórca dojrzały, uznany, uhonorowany większością nagród (...) decyduje się realizować chłopięce marzenia"53. Na taki scenariusz mogą wskazywać również inspiracje Zhanga. Reżyser pośród swoich mistrzów w pierwszej kolejności wymienia Stevena Spielberga ${ }^{54}$, twórcę lubującego się w rozmachu i teatralności, czyli atrybutach, na które w warunkach chińskich Zhang Yimou mógł sobie pozwolić dopiero u progu nowego tysiąclecia, w nowej rzeczywistości gospodarczej i z ugruntowaną pozycją w branży.

Inne spojrzenie na sprawę przedstawia Ni Zhen, pisarz, autor scenariuszy m.in. do filmów Zhanga Yimou, który mówi o reżyserze, że chciałby on „zmienić normy produkcji filmowej panujące w Chinach, podwyższyć poziom realizowanych filmów tak, żeby mogły osiagnąc status superprodukcji, w których grałyby wielkie gwiazdy. Zhang Yimou często mówi, że odbiorca zachodni kojarzy chińskie kino jedynie z kung-fu i filmami akcji. Dlatego pragnie podbić rynki zagraniczne, realizując filmy osadzone w tej tradycji. Jednak powinniśmy zadać sobie pytanie, dokąa zaprowadzi

50 Kino chinskie wczoraj...

51 A. Mikrut-Żaczkiewicz, Lou Ye..., s. 65.

52 A. Helman, Zhang Yimou..., s. 67.

53 Ibidem.

54 Zob. Y. Zhu, B. Robinson, The Cinematic Transition..., s. 150. 
nas takie przedstawianie narodu chińskiego i dziejów naszego kraju. To bardzo poważny problem" 55 .

Wydaje się zatem, że kontrowersje wokół nowej formuły zastosowanej przez Zhanga Yimou są uzasadnione, a sama orientacja na warsztat nie może w pełni usprawiedliwić strony merytorycznej twórczości. Podobnie rzecz ma się w przypadku innej linii obrony - odwoływania się do odmienności kulturowej Chin jako przyczyny niewłaściwego odczytania obrazów Zhanga przez zachodnią krytykę. Zgodnie z ową linią obrony „szczególnie Hero jest podatny na wypaczenia: widz zachodni odczytać może go jako pochwałę wyzbycia indywidualizmu i serwilizmu wobec władzy, tymczasem nie można zapominać, że film ten wywodzi się z tradycji chińskiego konfucjanizmu, który zbudował kulturę stawiającą społeczeństwo nad jednostką" 56 .

Biorąc pod uwage przedstawione wcześniej opinie chińskich reżyserów, można polemizować z teza, że problem tkwi w niewłaściwym odczytaniu filmów, wynikajacym z kulturowej odmienności widowni zachodniej. Co jednak godne podkreślenia, sam przywołany tutaj konfucjanizm nie zakładał bynajmniej bezmyślnego posłuszeństwa wobec wszechwładnego suzerena. Ważnym elementem całej doktryny był system etyczny, w którego centrum znajdowało się pięć cnót: ren - humanitaryzm, miłość altruistyczna, $y i$ - sprawiedliwość, $l i$ - wierność rytuałom, zhi- wiedza, xinzaufanie, wypełnianie obowiązków i wiara, że inni też będą je wypełniać. Władca, który nie jest „człowiekiem szlachetnym” i nie charakteryzuje się odpowiednimi cnotami, traci moralną legitymację do sprawowania władzy. Ilustruje to starsze od konfucjanizmu, ale zasymilowane przezeń pojęcie mandatu Niebios - władza pochodzi z „bożego nadania”, ale tym, kto wypełnia „wolę Nieba”, uznając autorytet władcy bądź buntując się przeciwko niemu, jest prosty lud. Działanie zasady mandatu Niebios uwidoczniło się w licznych powstaniach chłopskich, które w długiej historii Państwa Środka wielokrotnie przyczyniały się do upadku rządzących dynastii. Patrząc na postaci władców w Hero i Cesarzowej przez pryzmat filozofii konfucjańskiej, nie widzimy wcale „ludzi szlachetnych”. W obu filmach mamy do czynienia z tyranami opierającymi swoją władzę na brutalnej sile, nie zaś na wartościach etycznych uznawanych przez Konfucjusza za kluczowe dla harmonijnego funkcjonowania kolektywnego społeczeństwa, jakim jest niewątpliwie społeczeństwo chińskie. Także ten argument sam w sobie trudno więc uznać za rozstrzygający o „niewinności” reżysera.

Jeżeli już bronić autora, to raczej poprzez odwołanie się do jego wcześniejszej twórczości. O ile bowiem na pierwszy rzut oka w przedstawianych w niniejszym artykule cyklach obrazów dostrzega się przede wszystkim różnice, o tyle wnikliwe wczytanie się pozwala również zauważyć pewne podobieństwa. Tragizm położenia

55 Kino chinskie wozoraj...

56 A. Wycisk, Miedzy sqtukq..., s. 292. 
jednostki w społeczeństwie kolektywnym, nawet jeżeli zepchnięty na dalszy plan, stanowi ważny motyw filmów wuxia Zhanga, podobnie jak w przypadku jego pierwszych obrazów. Przesunięcie sympatii autora w stronę władzy może wynikać z faktu, że w Chinach epoki posttiananmeńskiej suzeren rzeczywiście w coraz większym stopniu spełnia oczekiwania ludu. „Można być dumnym z dzisiejszych, wciąż czerwonych, Chin i wielu Chińczyków to właśnie czuje"57.

Porażka indywiduum nie jest ani trochę mniej tragiczna przez to, że zbiorowości wiedzie się dobrze. Nie wydaje się też, by Zhang Yimou w jakikolwiek sposób kwestionował to w swoich filmach z gatunku wuxia. Wybór, jakiego dokonuje Bezimienny w Hero, należy w kategoriach symbolicznych rozpatrywać jako akceptacje mandatu Nieba dla władcy wprawdzie okrutnego, ale jednocześnie takiego, którego panowanie w dłuższej perspektywie może przynieść korzyść całej społeczności. Warto mieć na uwadze (a zdaje się, że większości komentatorów umknął ów fakt), że odwołanie się do postaci pierwszego cesarza kryje w sobie także ostrzeżenie. Ostatecznie „terrorystyczny system rządów" ${ }^{58}$ dynastii Qin doprowadził do jej upadku po zaledwie 15 latach panowania, co uczyniło ją najkrócej rządzącą dynastią w historii cesarstwa.

Z punktu widzenia zachodniej etyki ideologiczna wolta, jakiej dokonał Zhang Yimou wraz z Hero, może być rozpatrywana jako kontrowersyjny akt uznania zasadności zła. W kulturze chińskiej jednak zło i dobro jako bieguny moralności nie sa jasno zdefiniowane. Jest za to gra przeciwieństw i dao, porządek wszechświata, zgodnie z którym zawsze przychodzi moment całkowitej dominacji jednego pierwiastka - ciemności, zastoju, chłodu, który następnie ustępuje miejsca swojemu przeciwieństwu - światłu, energii, ciepłu; i tak w nieskończoność. A Zhang Yimou, artysta wrażliwy na „ducha czasów”, pełni funkcję kronikarza tych przemian, jego twórczość to lustro, w którym odbijają się kolejne fazy cyklu. Zhang patrzy zatem na wydarzenia nie tylko z perspektywy indywidualnej (chociaż nie ucieka od niej - tragizm jednostki jest jednym z ewidentnych lejtmotywów jego twórczości), ale także z - charakterystycznej dla Dalekiego Wschodu - perspektywy kosmicznej, w której hołubiona przez Zachód jednostka stanowi przede wszystkim część większej całości.

\section{Napisy końcowe}

Po Cesarzowej w twórczości Zhanga Yimou coraz trudniej doszukać się prawidłowości. Z jednej strony reżyser kontynuuje flirt z kinem wysokobudżetowym, sięgając w swoich produkcjach po gwiazdy Hollywoodu, np. Christiana Bale’a w Kwiatach

57 M. Jacoby, Chiny bez makijażu, Warszawa 2016, s. 248.

58 W. Rodziński, Historia..., s. 74. 
wojny (Jinling Shisan Chai, 2011) czy Matta Damona w Wielkim Murze (Changcheng, 2016), z drugiej powraca do tematu rewolucji kulturalnej w kameralnych obrazach Pod krz̧ewem głogu (Shanz̧hashu Zhi Lian, 2010) i Powrót do domu (Guilai, 2014). Być może właśnie owa bipolarność mogłaby posłużyć za podsumowanie drogi całego pokolenia. Piąta generacja tworzyła w czasach, które wymagały znalezienia właściwej proporcji między sztuką a komercją ${ }^{59}$ - z jednej strony, by zmieścić się w granicach swobody artystycznej narzuconych przez komunistyczne władze, z drugiej zaś - by sprostać wyzwaniom nowej, wolnorynkowej rzeczywistości. Precedensu dostarczył wspomniany już Wu Tianming, który w swoim studio w Xi'an umiejętnie łączył projekty komercyjne $\mathrm{z}$ artystycznymi, finansując te drugie dzięki zyskom z pierwszych. We współczesnym Państwie Środka (rozumianym też jako środek między parami przeciwieństw: indywidualizmem i kolektywizmem, sztuką i komercją, kapitalizmem i komunizmem) również artyści uprawiają „wielką sztukę przetrwania”, czyli robią to, co w zachodnim świecie zawiera się w biblijnej maksymie: „Bogu co boskie, cezarowi co cezara”. Wydaje się zatem, że nie ma dobrej odpowiedzi na pytanie postawione w temacie artykułu. Zhang Yimou jest zarówno twórca niezależnym, jak i koniunkturalnym albo nie jest żadnym z nich, a po prostu twórca, w którego dziele odbija się cała dwubiegunowość czasów, w których przyszło mu żyć i tworzyć.

Warto zwrócić uwagę, że podobne metamorfozy stały się udziałem także pozostałych czołowych przedstawicieli pokolenia. Artystyczne apogeum przypadło na pierwsza połowę lat 90., kiedy to powstały takie dzieła, jak Żegnaj, moja konkubino (Bawang bie ji, 1993) Chena Kaige czy Btekitny latawiec (Lan fengzhen, 1993) Tiana Zhuangzhuanga. W 1998 r., 4 lata przed Hero, Chen Kaige nakręcił wysokobudżetowego Cesarza i zabójce (Jing Ke Ci Qin Wang), kilka lat później na poły baśniowa Praysiege (Wuji, 2005), a ostatnimi czasy - animowanego Kükai (Yao Mao Zhuan, 2017). W międzyczasie wyreżyserował też produkcję zachodnią - Urok mordercy (Killing me softly, 2002). Najbardziej niepokorny z wielkiej trójki Tian Zhuangzhuang po Błękitnym latawcu trafił na czarną listę chińskiej cenzury i poświęcił się współpracy z młodym pokoleniem twórców - szóstą generacją ${ }^{60}$. Po powrocie z artystycznego niebytu nakręcił parę kameralnych obrazów i dopiero w 2009 r. wyreżyserował wysokobudżetowy dramat kostiumowy Wojownik i wilk (Lang zai ji, 2009), który nie spotkał się jednak z przychylnym przyjęciem krytyki ani publiczności i pozostaje jak dotąd ostatnim filmem reżysera.

Na koniec warto odnotować, że artystyczni następcy wielkiej trójki - reżyserzy szóstej generacji, tacy jak Jia Zhangke, Wang Xiaoshuai, Lou Ye czy Zhang Yuan, poszli zupełnie inną droga. Podczas gdy twórczość ich starszych kolegów osiagała etap wysokobudżetowych spektakli historycznych, młodzi filmowcy two-

59 Zob. Y. Zhu, B. Robinson, The Cinematic Transition..., s. 145-161.

60 Ibidem, s. 153. 
rzyli „przede wszystkim produkcje prawdziwe, mocno osadzone w rzeczywistości i sytuacjach dnia codziennego" ${ }^{61}$. Ta zasadnicza różnica w podejściu do sztuki filmowej wynika z zasygnalizowanego już w niniejszym artykule odmiennego podłoża ideologicznego, na którym wyrosło nowe pokolenie. Możliwość swobodnego obcowania z zachodnią kulturą w latach 80., kiedy kształtował się światopogląd szóstej generacji, sprawiła, że wrażliwość twórców nowej fali przesunęła się w kierunku wartości zachodnich. Kultura popularna, w szczególności muzyka, poprzez zwrócenie odbiorcy w stronę jego własnych uczuć i potrzeb wprowadziła do kolektywnego społeczeństwa pierwiastek indywidualności. Pokazuje to tylko, jak istotną rolę w kształtowaniu postawy artysty odgrywa tło społeczno-polityczne. Toteż podobne rozważania dla szóstego pokolenia chińskich twórców z konieczności pobiegłyby innymi torami, ale to temat na osobny artykuł.

\section{SUMMARY \\ ZHANG YIMOU - INDEPENDENT DIRECTOR \\ OR SUPPORTER OF THE STATE? ONE ARTIST'S METAMORPHOSIS IN A COMMUNIST COUNTRY}

This article describes how different attitudes towards reality develop as a result of living under a communist regime that undergoes dynamic economic and social transformation. The main focus is placed on Zhang Yimou, the renowned Chinese director, whose life and work seem to reflect on-going changes in a unique way, showing a pattern closely correlated with the political and social situation in China. The author describes how two major revolutions, the Cultural Revolution and the following economic transformation of China, shaped the life of Zhang and influenced his work. When analyzed in depth, his movies form cycles which coincide with the rapidly changing social and political circumstances. Three such cycles are described: an independent movie-making stage, developing around the early stages of economic transformation and the events in Tiananmen Square in 1989; an intermediate stage related to the development of a new, semi-capitalist society in the nineties; and finally, a commercial stage related to the great economic boom of the first decade of the twenty-first century.

${ }^{61}$ A. Wycisk, Miedsy sætukq..., s. 293. 